\title{
IN VITRO COMPARISON OF THE CARIOSTATIC EFFECT BETWEEN TOPICAL APPLICATION OF FLUORIDE GELS AND FLUORIDE TOOTHPASTE
}

\author{
COMPARAÇÃO IN VITRO DO EFEITO CARIOSTÁTICO ENTRE A APLICAÇÃO TÓPICA \\ DE FLÚOR E DENTIFRÍCIO FLUORETADO
}

\begin{abstract}
Alberto Carlos Botazzo DELBEM ${ }^{1}$, Fernanda Lourenção BRIGHENTI ${ }^{2}$, Ana Elisa de Mello VIEIRA ${ }^{2}$, Jaime Aparecido CURY ${ }^{3}$
\end{abstract}
\author{
1- Assistant Professor, Araçatuba Dental School, Sao Paulo State University (UNESP). \\ 2- Post-Graduate Student, Araçatuba Dental School, Sao Paulo State University (UNESP). \\ 3- Professor, Piracicaba Dental School, University of Campinas (UNICAMP).
}

Corresponding address: Alberto Carlos Botazzo Delbem - Faculdade de Odontologia de Araçatuba - UNESP - Disciplina de Odontopediatria Rua José Bonifácio 1193 - Araçatuba - SP - Brasil - Cep 16015-050 - Fax: 551836364890 - e-mail: adelbem@foa.unesp.br

Received: September 15, 2003 - Returned for modification: December 12, 2003 - Accepted: February 2, 2004

\begin{abstract}
$7 \Gamma$

Ihe aim of this study was to compare the effect of topical fluoride products [acidulated phosphate fluoride (APF) or neutral gel (NF) x fluoride toothpaste (MFP)], in respect to fluoride uptake and anticariogenic action. One hundred and twenty five blocks of human teeth, sorted in 5 groups according to the treatment, were submitted to $\mathrm{pH}$ cycling for ten days. The parameters analyzed were: fluoride uptake before and after $\mathrm{pH}$ cycling and surface (SMH) and cross-sectional (CSMH) microhardness of the enamel blocks. The results of fluoride concentration in enamel after the $\mathrm{pH}$ cycling showed an enhancement of fluoride uptake for all groups compared to sound control. No significant differences between APF and MFP were observed for surface microhardness, percentage change of surface microhardness and mineral loss. The volume percent mineral obtained from cross-sectional microhardness demonstrated that APF has a different lesion progression rate regarding subsurface carious lesion. The results suggest that professionally applied fluoride gel or frequent fluoride application in low concentration is a positive preventive measure for the control of dental caries.
\end{abstract}

UNITERMS: Dental Caries, prevention \& control; Fluoride.

\section{RESUMO}

O

objetivo do presente estudo foi comparar in vitro o efeito da aplicação tópica de flúor na forma de gel acidulado (FFA) ou neutro (FFN) com um dentifrício fluoretado (MFP), na incorporação e ação anticariogênica do flúor. Foram utilizados 125 blocos obtidos de esmalte humano, divididos em 5 grupos de acordo com o tratamento e submetidos à ciclagem de pH durante dez dias. Analisou-se o flúor incorporado antes e depois da ciclagem de pH; a microdureza superficial (SMH) e a microdureza interna do esmalte (CSMH). Os resultados da concentração de flúor no esmalte após a ciclagem indicou uma maior quantidade de flúor incorporado para todos os grupos comparados ao grupo controle sadio. A microdureza superficial entre APF e MFP, assim como a porcentagem de alteração da microdureza superficial e a perda mineral não mostraram diferenças estatísticas. A porcentagem de volume mineral obtida a partir da microdureza em secção longitudinal demonstrou que o APF tem um padrão melhor na formação da cárie subsuperficial. Os resultados sugerem que o uso de géis acidulados ou a freqüente aplicação de flúor em baixa concentração são medidas eficazes para o controle da cárie dental.

UNITERMOS: Cárie dentária, prevenção \& controle; Flúor.

\section{INTRODUCTION}

According to Clarkson ${ }^{2}$, the reduction in dental caries prevalence observed during the last decades is explained by the wide use of fluoride. Tooth decay is a consequence of the unbalance between the demineralization and remineralization process. Fluoride present in plaque and enamel fluids can control the development of tooth decay, 
inhibiting demineralization and activating the remineralization process. Published studies suggest that this reduction is mainly related to the use of topical fluoride products, such as toothpastes and gels.

In Brazil, only $25 \%$ of the toothpastes available on the market were fluoridated ${ }^{3}$ before September 1988. At that time, fluoride was added to the toothpaste "Kolynos Super Branco"* . Today this brand has a market share of about $50 \%$. The greatest advantage of fluoride toothpastes compared to other forms of topical application is the regular exposure to low fluoride concentration, providing small fluoride concentration increases in the enamel surface ${ }^{15}$. There is strong evidence that the low prevalence of tooth decay in developed countries is owed to the widespread use of fluoridated toothpastes ${ }^{1}$.

Convenience, acceptance by the patients, short application time and satisfactory results are some of the reasons that justify the wide use of fluoridated gels by dentists ${ }^{11,24}$.

Heath, et al. ${ }^{10}$ evaluated fluoride concentration in saliva after the use of toothpastes, mouthwashes and gels administered in different ways and concluded that salivary retention does not necessarily measure the amount of fluoride incorporated in enamel and, as a consequence, the final effect of the analyzed products. Therefore, in order to evaluate the effectiveness of fluoridated products available, in vitro and in vivo studies are required.

Hence, the purpose of the present study was to compare the effect of professionally applied acidulated or neutral gels with fluoride toothpaste, in relation to fluoride incorporation and cariogenic action.

\section{METHODS}

\section{Experimental Design}

One hundred and twenty-five enamel blocks measuring $4 \times 4 \mathrm{~mm}$ obtained from impacted human third molars were stored in $2 \%$ formaldehyde solution $\mathrm{pH} 7.0^{22}$ for one month. The surface of these blocks was polished to remove approximately $50 \mu \mathrm{m}$ of enamel ${ }^{8}$, which led to their selection through surface microhardness analysis. Thus, the 125 enamel blocks were randomized in 5 groups. One hundred blocks were submitted to $\mathrm{pH}$ cycling during 10 days. Treatment with acidulated or neutral gels was done immediately before the $\mathrm{pH}$ cycling. The blocks of the fluoride dentifrice group received daily treatments during $\mathrm{pH}$ cycling. The enamel blocks of the sound control (SC), neutral gel (NF) and acidulated gel (APF) groups, which were not submitted to $\mathrm{pH}$ cycling, were stored in humid formaldehyde environment for further analysis. After the experiment, surface and cross-sectional enamel microhardness and fluoride determination were made in all enamel blocks, including those not submitted to $\mathrm{pH}$ cycling.

\section{Division of the groups}

The 125 blocks were randomized in 5 groups:

- acidulated gel - APF $(n=31)$ : treatment with acidulated phosphate fluoride gel. Fluoride uptake was evaluated immediately after the gel application $(\mathrm{n}=10)$ or after the $\mathrm{pH}$ cycling $(n=10)$; surface and cross-sectional microhardness were performed in 11 blocks;

- neutral gel - NF $(n=31)$ : treatment with sodium fluoride neutral gel. Fluoride uptake was evaluated immediately after the gel application $(n=10)$ or after the $\mathrm{pH}$ cycling $(n=10)$; surface and cross-sectional microhardness were performed in 11 blocks;

- fluoride toothpaste - MFP ( $n=21)$ : the treatments were carried out twice a day with a monofluorphosphate dentifrice during the $\mathrm{pH}$ cycling. Fluoride uptake was evaluated in ten blocks after submitting them to $\mathrm{pH}$ cycling; surface and cross-sectional microhardness were performed in 11 blocks;

- carious control - CC $(n=21)$ : the blocks did not receive any treatment during the $\mathrm{pH}$ cycling. Fluoride uptake was evaluated immediately after the $\mathrm{pH}$ cycling $(n=10)$; surface and cross-sectional microhardness were performed in 11 blocks;

- sound control - SC ( $n=21)$ : these blocks were not submitted to $\mathrm{pH}$ cycling. Fluoride uptake was evaluated before the $\mathrm{pH}$ cycling $(\mathrm{n}=10)$; surface and cross-sectional microhardness were performed in 11 blocks;

\section{Treatments and $\mathrm{pH}$ cycling}

The blocks of each group were submitted for 10 days to a pH cycling model simulating a high cariogenic challenge, based on Featherstone, et al. ${ }^{7}$. The blocks were kept in a demineralizing solution ( $2.0 \mathrm{mmol} \mathrm{L}^{-1}$ calcium, $2.0 \mathrm{mmol} \mathrm{L}^{-1}$ phosphate in $0.075 \mathrm{~mol} \mathrm{~L}^{-1}$ acetate buffer, $\mathrm{pH}$ 4.3) for $6 \mathrm{~h}$ (20 $\mathrm{mL}$ per block), and in a remineralizing solution (1.5 mmol $\mathrm{L}^{-1}$ calcium, $0.9 \mathrm{mmol} \mathrm{L}^{-1}$ phosphate, $150 \mathrm{mmol} \mathrm{L}^{-1}$ of $\mathrm{KCl}$ in $0.1 \mathrm{~mol} \mathrm{~L}^{-1}$ Tris buffer, $\mathrm{pH} 7.0$ ) for $18 \mathrm{~h}$ (10mL per block). During the weekend, the enamel blocks were stored in the remineralizing solution; fresh de- and remineralization solutions were used for the next 5 days. Residual fluoride was found in the fresh demineralizing $(0.08 \mathrm{ppm})$ and remineralizing $(0.07 \mathrm{ppm})$ solutions.

All blocks' surfaces were protected with wax, except for a circular area of enamel measuring $3.14 \mathrm{~mm}^{2}$. Before the $\mathrm{pH}$ cycling, the enamel blocks from the APF and NF groups were submitted to fluoride gel treatment with acidulated fluoride (Nupro - Dentsply Industries, Petrópolis, RJ, Brazil, $1.23 \% \mathrm{~F}, 0.1 \mathrm{~mol} \mathrm{~L}^{-1}$ of phosphoric acid, $\mathrm{pH} 3.6$ to 3.9) or sodium fluoride neutral (Nupro - Dentsply Industries, Petrópolis, RJ, Brazil, 2\% NaF, pH 6.5 to 7.5), which were applied for 4 minutes using a cotton swab. After application, excess gel was removed with cotton wool and the blocks were immersed in stimulated human saliva (1.0mL per block) during $30 \mathrm{~min}$ to simulate the residual effect of fluoride in

\footnotetext{
* Nowadays named Sorriso (1500 ppm F as sodium monofluorphate)
} 
saliva that occurs after a professional topical application. The blocks were washed with a jet of deionized water for approximately 30s and lightly dried with absorbent paper.

The blocks from the MFP group were submitted to dentifrice treatment during the $\mathrm{pH}$ cycling. A fluoridated dentifrice (MFP) containing 1,200 $\mu$ g F/g from $\mathrm{Na}_{2} \mathrm{FPO}_{3}$ $\mathrm{CaCO}_{3}$-based abrasive (Sorriso, Kolynos of Brazil) was used. The treatment regimen consisted of 5-min soaks under agitation in $30 \mathrm{~mL}$ of $33 \%$ (w/v) dentifrice/stimulated human saliva slurries, 2 times a day (before and after a demineralizing period) to simulate tooth-brushing exposure.

\section{Microhardness Analysis}

Surface and cross-sectional enamel microhardness measures were made using a Shimadzu HMV-2000 microhardness tester (Shimadzu Corporation, Kyoto, Japan). For surface microhardness (SMH), five indentations were made in the center of the enamel block, as described by Delbem and Cury ${ }^{5}$.

To perform cross-sectional microhardness (CSMH) tests, the blocks were longitudinally sectioned through the center of the isolated area. The two halves were embedded in acrylic resin so that the cut section was exposed and gradually polished. Three sequences of eight indentations were made at $20,40,60,80,100,120,240$ and $480 \mu \mathrm{m}$ from the outer enamel surface, spaced $100 \mu \mathrm{m}$ from each other ${ }^{5}$. The mean values were calculated at each distance and the values were converted to mineral content (volume percent mineral $\mathrm{x} \mu \mathrm{m})^{6}$. Then, mineral loss $(\Delta \mathrm{Z})$ was calculated subtracting the area under the curve of sound control blocks from the area under the curve of each treatment. The result was used to compare the groups.

\section{Analysis of Fluoride Concentration in Enamel}

Fluoride concentration was evaluated in sound enamel, after fluoride gel application (before $\mathrm{pH}$ cycling) and after the $\mathrm{pH}$ cycling. From each block, a layer of enamel was removed by immersion in $0.5 \mathrm{~mL}$ of $0.5 \mathrm{~mol} \mathrm{~L}^{-1} \mathrm{HCl}$ for $60 \mathrm{~s}$ under agitation. Fluoride was determined according to Koo and Cury ${ }^{13}$ and was expressed in $\mu \mathrm{g} \mathrm{F} / \mathrm{mm}^{2}$ of enamel. The amount of enamel removed by the biopsy was calculated by the colorimetric determination of inorganic phosphorus using a digital spectrophotometer (U-100 Spectrophotometer Hitachi), as described by Fiske and Subarrow ${ }^{9}$. An enamel layer of $41.8 \pm 2.2 \mu \mathrm{m}$ (mean $\pm \mathrm{SD}$ ) was removed from the blocks.

\section{Statistical Analysis}

Data obtained from the enamel fluoride concentration and \% vol. min. $\mathrm{x} \mu \mathrm{m}$ was submitted to the analysis of variance and to the Tukey test at $5 \%$ of significance. For $\mathrm{SMH}, \% \mathrm{SMHC}$ and $\Delta \mathrm{Z}$, the non-parametric multiple comparisons tests (Kruskall-Wallis) were applied to distinguish significant differences between the treatments at $5 \%$.

\section{RESULTS}

\section{Microhardness of Enamel Blocks}

Table 1 shows that surface microhardness of enamel (SMH) was significantly higher in the enamel blocks treated with fluoride dentifrice (MFP) and acidulated gel (APF) when compared to carious control and neutral gel $(\mathrm{p}<0.05)$. The $\mathrm{APF}$ and MPF groups also showed the greater reduction in mineral loss. However, no significant differences were observed between these two treatments. Also, it was verified that the enamel blocks treated with neutral gel showed significantly higher surface microhardness values leading to a reduction in mineral loss when compared to carious control. All treatment groups showed significantly lower surface microhardness and an increase in mineral loss when compared to sound control. Figure 1 shows the percent mineral loss vs. depth for each treatment. It was possible to observe that APF had an enhancement on \% vol min at the distance from $20 \mu \mathrm{m}$ to $40 \mu \mathrm{m}$ of depth while the other treatments had this enhancement only at the interval from $40 \mu \mathrm{m}$ to $60 \mu \mathrm{m}$ of depth.

TABLE 1- Enamel blocks analyses according to the treatment (mean $\pm S D, n=11$ )

\begin{tabular}{|c|c|c|c|}
\hline \multirow[b]{2}{*}{ TREATMENT } & \multicolumn{3}{|c|}{ ANALYSES } \\
\hline & $\mathrm{SMH}^{*}$ & $\%$ SMHC ** & $\Delta Z^{* * *}$ \\
\hline SC & $352.0 \pm 4.1^{\mathrm{a}}$ & - & - \\
\hline $\mathrm{CC}$ & $95.2 \pm 5.9^{b}$ & $-74.3 \pm 4.1^{a}$ & $4074.9 \pm 1494.6^{a}$ \\
\hline APF & $152.2 \pm 12.2^{c}$ & $-54.7 \pm 11.3^{b}$ & $909.7 \pm 400.3^{b}$ \\
\hline $\mathrm{NF}$ & $124.2 \pm 7.6^{d}$ & $-66.4 \pm 4.7^{c}$ & $2637.8 \pm 1221.7^{c}$ \\
\hline MFP & $168.3 \pm 10.1^{c}$ & $-54.2 \pm 7.4^{b}$ & $1256.7 \pm 498.1^{b}$ \\
\hline
\end{tabular}

Means followed by distinct letters are statistically different $(p<0.05)$. *Surface microhardness, **Percentage of enamel surface microhardness change, ${ }^{* * *}$ Mineral loss. 


\section{Analysis of Fluoride Concentration in Enamel}

With respect to fluoride $\left(\mathrm{mg} / \mu \mathrm{m}^{2}\right)$ in enamel at $41.8 \pm$ $2.2 \mu \mathrm{m}$ from the surface, the data (table 2) showed higher concentration in enamel blocks for APF and NF groups when compared to sound control group $(\mathrm{p}<0.05)$. The fluoride concentration in enamel due to the previous acidulated gel application (APF) decreased significantly after $\mathrm{pH}$ cycling, but increased with neutral gel (NF) treatment $(\mathrm{p}<0.05)$. The concentration of fluoride in enamel blocks for groups CC, $\mathrm{APF}$ and NF was lower than that for MFP group $(\mathrm{p}<0.05)$; however, the differences between them were not significant $(\mathrm{p}>0.05)$.

\section{DISCUSSION}

The APF gel applications as well as fluoride toothpastes have been used extensively and their anticariogenic properties have been evaluated through laboratory, clinical and epidemiological studies.

The aim of the present study was to compare, in vitro, the effect of topical application of acidulated or neutral gel with a fluoride toothpaste, in relation to the incorporation and anticariogenic action of fluoride. There are no data comparing the cariostatic effect of those products in a caries dynamics protocol, which has an acid phase and a remineralizing period with the presence of calcium, phosphate and a low fluoride concentration similar to the mouth's cariogenic challenge. According to ten Cate ${ }^{20}$, the best way to simulate the in vivo environment is through the use of in vitro cycling demineralization/remineralization model, which is equivalent to the dynamics of tooth decay development. In order to get valid results, the in vitro studies should use methodologies that simulate what happens in the mouth ${ }^{4}$ as well as techniques with results presenting correlation with in vivo studies ${ }^{18}$. Thus, since the developed formulation is not totally innovated, these tests, when appropriately delineated, can attest equivalence of relative

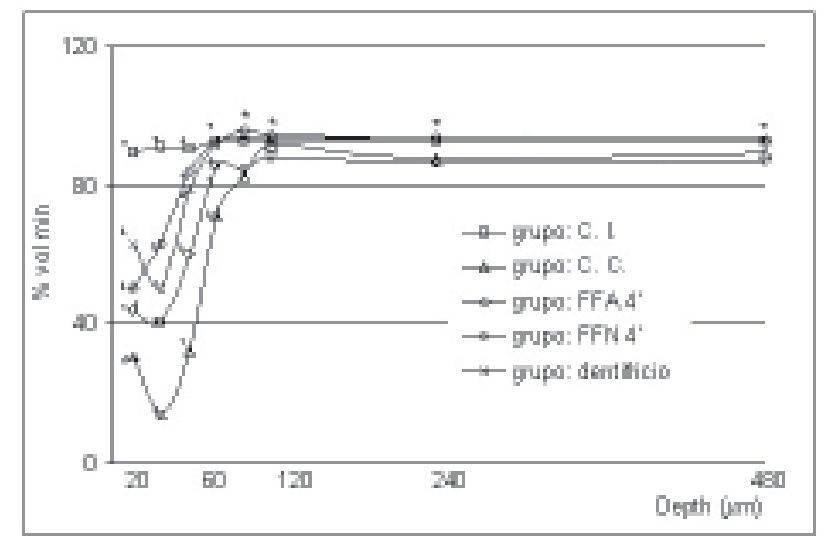

FIGURE 1- Microhardness profiles as volume percent mineral (\% vol min) versus distance from outer enamel (ìm) according to the treatment $(n=11)$. Means followed by distinct letters are statistically different $(p<0.05)$. effect to clinical studies.

The present study used a $\mathrm{pH}$ cycling $\operatorname{model}^{7}$, which simulates a high cariogenic challenge during 4 weeks. The 6-hour acid challenge has clinical correlation to what happens when the patient frequently ingests sugarcontaining products and fails to remove dental plaque. The 5-min soaks of toothpaste treatment simulate the retention period of fluoride in the mouth and the remineralization solution mimics the saliva repair period ${ }^{7}$. Therefore, the results of this study may have some correlation with the clinical situation.

The purpose of SMH evaluation was supported by White ${ }^{22}$ that a strong correlation $(r=0.94)$ may be achieved between remineralization measured by this technique and enamel remineralization measured radiographically. Crosssectional microhardness was used according to Featherstone, et al. ${ }^{6}$ and Kielbassa, et al. ${ }^{12}$ to evaluate the resistance to demineralization considering that there is a good correlation $(r=0.91)$ between enamel microhardness and mineral loss in carious lesion.

When fluoride is present, a reduction in mineral loss and fluoride uptake by the enamel happens simultaneously during the development of tooth decay. Although the carious control group was not treated with fluoride, the fluoride concentration was similar to APF and NF after the $\mathrm{pH}$ cycling. Also, the group treated with neutral gel presented a statistically higher fluoride concentration after the $\mathrm{pH}$ cycling when compared to the values previously obtained and significant differences were observed between APF and NF before the $\mathrm{pH}$ cycling. These observations are probably due to the fluoride presence in the demineralization and remineralization solutions; at lower $\mathrm{pH}$ more enamel is dissolved during the demineralization phase of the cycle, providing additional reactive sites (porosities); and the decay process causes reduction in the crystals' size $\mathrm{e}^{21,23}$.

TABLE 2- Fluoride uptake in enamel $\left(\mathrm{mg} \mathrm{F} / \mu \mathrm{m}^{2}\right.$ ) before and after $\mathrm{pH}$ cycling according to the treatment (mean \pm $\mathrm{SD} ; \mathrm{n}=10$ )

\begin{tabular}{lcc}
\hline TREATMENTS & $\begin{array}{l}\text { BEFORE pH- } \\
\text { CYCLING }\end{array}$ & $\begin{array}{l}\text { AFTER pH- } \\
\text { CYCLING }\end{array}$ \\
\hline SC & $4.7 \pm 2.9^{\mathrm{a}}$ & - \\
CC & - & $12.9 \pm 4.1^{\mathrm{b}, \mathrm{d}}$ \\
APF & $16.3 \pm 4.4^{\mathrm{b}}$ & $12.3 \pm 4.0^{\mathrm{d}}$ \\
NF & $8.4 \pm 3.9^{\mathrm{c}}$ & $12.3 \pm 2.7^{\mathrm{d}}$ \\
MFP & - & $21.9 \pm 4.2^{\mathrm{e}}$ \\
\hline
\end{tabular}

Means followed by distinct letters are statistically different $(p<0.05)$.

Letters show difference between fluoride concentration in enamel, before and after $\mathrm{pH}$ cycling, for each group as well as between groups. 
It was not possible to observe a typical subsurface carious lesion in the APF group (fig 1). Unlike the values obtained from enamel surface microhardness analysis, the results of mineral loss $(\Delta \mathrm{Z})$ showed that the treatment with APF did not statistically differ from the treatment with fluoride toothpaste. These results suggest that APF may have a different lesion progression rate when compared to neutral gel or fluoride toothpaste. At $60 \mu \mathrm{m}$, both MFP and APF treatments did not statistically differ from sound control.

It is known that not all soluble fluoride is active on in vitro tests ${ }^{7,22}$. In this study, the presence of soluble fluoride on MFP group can be confirmed by the reduction of $\%$ SMHC and $\Delta \mathrm{Z}$, as well as by the highest fluoride uptake value after the $\mathrm{pH}$ cycling. This result was obtained mainly because human saliva was used to better simulate the hydrolysis that occurs in the oral cavity due the presence of phosphatases ${ }^{16}$.

According to Padilla and Davis ${ }^{17}$, the most important mode of action of fluoride occurs through low and constant fluoride levels in the saliva. Fluoride toothpaste is an important way for prevention and/or remineralization of initial carious lesions since it is widely used. The key for improving oral health is the use of appropriate fluoride toothpaste associated to satisfactory oral hygiene.

Regarding cost-benefit relationships, the use of professionally applied fluoride gels has been questioned in children with low caries experience. Therefore, the daily use of fluoride gels during toothbrushing has been suggested ${ }^{14}$. This could add the benefit of a product with anticariogenic ability to the low cost and short operational time of selfapplied procedures. APF can be of great usefulness in countries with high caries activity, low level of basic prevention and a disorganized oral health care system. In those countries, any preventive program seems to be effective ${ }^{19}$ since effective and free of charge oral health care is not supplied to the population ${ }^{14}$.

The results of the present work showed that products with high fluoride concentration could be tested in patients with caries activity until lesion arrestment. Frequent fluoride application in low concentration could also be efficient for tooth decay control. The regular use of fluoride toothpastes could be a beneficial preventive measure for all countries, independent of caries experience and oral health care.

\section{ACKNOWLEDGEMENTS}

The authors thank Miss Mariza de Jesus Carlos Soares and Mr. Waldomiro Vieira Filho for technical assistance. This publication was based on a thesis submitted by the first author to Araçatuba Dental School, UNESP, in partial fulfillment of the requirements for an MS degree in Pediatric Dentistry.

\section{REFERENCES}

1- Brambilla E. Fluoride: is it capable of fighting old and new dental diseases? Caries Res 2001 May/June; 35 Suppl 1:6-9.

2- Clarkson JJ, McLoughlin J. Role of fluoride in oral health promotion. Int Dent J 2000 Jun; 50(3):119-8.

3- Cury JA. Dentifrícios antiplaca no Brasil: avaliação do flúor. Rev Assoc Paul Cir Dent 1988 Mar/Abr; 42(2):168-70.

4- Davidson CL, Hoekstra IS, Arends J. Microhardness of sound, decalcified and etched tooth enamel related to the calcium content. Caries Res 1974 June/Aug; 8(2):135-44.

5- Delbem ACB, Cury JA. Effect of application time of APF and $\mathrm{NaF}$ gels on microhardness and fluoride uptake of in vitro enamel caries. Am J Dent 2002 June;15(3):169-72.

6- Featherstone JDB, ten Cate JM, Shariati M, Arends, J. Comparison of artificial caries-like lesions by quantitative microradiography and microhardness profiles. Caries Res 1983 Oct/Nov; 17(5):385-91.

7- Featherstone JDB, O’Reilly MM, Shariati M, Brugler S. Enhancement of remineralisation in vitro and in vivo. Factors relating to demineralisation and remineralisation of the teeth. Oxford: IRL Press, 1986. p.23-34.

8- Featherstone JDB, Zero DT. An in situ model for simultaneous assessment of inhibition of demineralization and enhancement of remineralization. J Dent Res 1992 Apr; 71(sp. Issue):804-10.

9- Fiske $\mathrm{CH}$, Subbarow Y. The colorimetric determination of phosphorus. J Biol Chem 1925; 66:375-400.

10- Heath K, Singh V, Logan R, McIntyre J. Analysis of fluoride levels retained intraorally or ingested following routine clinical applications of topical fluoride products. Aust Dent J 2001 Mar; 46(1):24-31.

11- Johnston DW. Current status of professionally applied topical fluorides. Comm Dent Oral Epidemiol 1994; 22:159-63. In: Brambilla E. Fluoride. Is it capable of fighting old and new dental diseases? Caries Res 2001 May/June; 35(Suppl 1):6-9.

12- Kielbassa AM, Wrbas KT, Schulte-Monting J, Hellwig E. Correlation of transversal microradiography and microhardness on in situ-induced demineralization in irradiated and nonirradiated human dental enamel. Arch Oral Biol 1999 Mar; 44(3):243-351.

13- Koo H, Cury JA. Soluble calcium/SMFP dentifrice: effect on enamel fluoride uptake and remineralization. Am J Dent 1998 Aug; 11(4):173-6.

14- Maltz M, Barbachan e Silva B, Carvalho DQ, Volkweis A. Results after two years of non-operative treatment of occusal surface in children with high caries prevalence. Braz Dent $\mathrm{J}$ 2003;14(1):48-54.

15- Mellberg, JG, Chomicki, WG. Fluoride uptake by artificial caries lesions from fluoride dentifrices in vivo. J Dent Res 1983; 62:540-2. 
16- Pearce EI. Biochemistry of monofluorphosphate. Caries Res 1983; 17(suppl 1):21-35.

17- Padilla O, Davis MJ. Fluorides in the new millennium. N Y State Dent J 2001 Feb; 67(2):34-8.

18- Raven SJ, Schafer F, Duckworth RM, Gilbert RJ, Parr TA. Comparison between evaluation methods for the anti-caries efficacy of monofluorophosphate-containing dentifrices. Caries Res 1991 Apr/May; 25(2):130-7.

19- Seppa L. The future of preventive programs in countries with different systems for dental care. Caries Res 2001 Apr/May; 35(Suppl 1):26-9.

20- Ten Cate JM. In vitro studies on the effects of fluoride on deand remineralization. J Dent Res 1990 Feb; 69(sp Issue):614-9.

21- ten Cate JM, Buijs MJ, Damen JJ. pH-cycling of enamel and dentin lesions in the presence of low concentrations of fluoride. Eur J Oral Sci 1995 Dec; 103(6):362-7.

22- White DJ. Reactivity of fluoride dentifrices with artificial caries. I. Effects on early lesions: F uptake, surface hardening and remineralization. Caries Res 1987 Mar/Apr; 21(2):126-40.

23- White DJ, Nelson DGA, Faller RV. Mode of action of fluoride: application of new techniques and test methods to the examination of the mechanism of action of topical fluoride. Adv Dent Res 1994 July; 8(2):166-74.

24- Winston AE, Bhaskar SN. Caries prevention in the $21^{\text {st }}$ Century. J Am Dent Assoc 1998 Nov; 129(11):11579-87. 